\title{
Respon Fisiologi pada Pembibitan Mangga Kasturi (Mangifera casturi Kosterm) terhadap Aplikasi Cahaya LED (Light Emitting Diode)
}

\section{The Responses of Physiology in Kasturi Mango (Mangifera casturi Kosterm) Seedling to LED-Artificial Light Application}

\author{
Alifiya Herwitarahman', Roedhy Poerwanto ${ }^{2}$, Didy Sopandie ${ }^{2}$, dan Deden Derajat Matra ${ }^{2 *}$ \\ ${ }^{1}$ Program Studi Agronomi dan Hortikultura, Sekolah Pascasarjana, Institut Pertanian Bogor \\ ${ }^{2}$ Departemen Agronomi dan Hortikultura, Fakultas Pertanian, Institut Pertanian Bogor \\ (IPB University), Jl. Meranti, Kampus IPB Darmaga, Bogor 16680, Indonesia
}

Diterima 2 November 2021/Disetujui 19 Desember 2021

\begin{abstract}
Kasturi mango (Mangifera casturi Kosterm) is one of the endemic fruit trees from South Kalimantan, with extinct status in the wild by IUCN. Kasturi had a problem with a long period in the nursery due to juvenility. Artificial light such as LED lamps can cut the juvenile phase because it could increase photosynthetic efficiency. This research aimed to determine different responses of physiology seedling using an LED lamp. This research used nested design as the experimental design where Monochromatic LED as the main factor with three levels (red, white, and blue) and accessions as the second factor with three levels (Cuban, Pelipisan and Kasturi) that were nested on the main factor. LED light made different responses for chlorophyll content that red LED made the higher concentration of chlorophyll a, but not for chlorophyll b and the ratio. Blue LED made plants have higher light absorbance, stomata conductance, transpiration, $\mathrm{CO}_{2}$ interception, and photosynthetic rate in Kasturi accession higher than the other lamps. Blue light made glucose concentration on leaf higher, but fructose higher under white lamp than the other lamps. The application of white LED made leaf thicker than the other lamps. Based on this research, different LED light illumination made a different response on Kasturi seedling for cut juvenile phase.
\end{abstract}

Keyword: photosynthetic, chlorophyll ratio, fructose, glucose

\section{ABSTRAK}

Mangga Kasturi (Mangifera casturi Kosterm) merupakan mangga endemik Kalimantan Selatan dengan status langka di alamnya berdasarkan IUCN-red list. Kasturi dengan masa juvenil yang panjang sehingga menyebabkan awal pembuahan yang lama. Penggunaan cahaya buatan dengan lampu LED-light emmiting diode diketahui dapat memperpendek juvenilitas karena meningkatkan efisiensi fotosintesis. Penelitian ini bertujuan untuk mempelajari perbedaan respon fisiologi dari bibit mangga Kasturi menggunakan lampu LED. Penelitian ini menggunakan rancangan petak tersarang dengan faktor utama lampu LED dan faktor kedua aksesi sebagai perlakuan yang disarangkan. Faktor utama terdiri dari tiga taraf yaitu LED merah, putih dan biru, sedangkan faktor kedua terdapat tiga taraf yaitu aksesi Cuban, Pelipisan, dan Kasturi. Penggunaan LED memberikan beberapa perbedaan respon terhadap kandungan klorofil, LED merah menunjukan nilai paling tinggi pada kandungan klorofil a, tetapi tidak ada pengaruh pada klorofil b dan rasio klorofil. Penyinaran LED biru menunjukkan nilai absorsi cahaya, konduktansi stomata, transpirasi, dan laju fotosintesis yang lebih tinggi pada aksesi Kasturi. Lampu LED biru meningkatkan kandungan glukosa, sedangkan lampu LED putih membuat kandungan fruktosa yang lebih tinggi dibandingkan lampu lain dan mempengaruhi ketebalan daun yang lebih tebal. Berdasarkan penelitian ini monokromatik LED memberikan pengaruh berbeda pada setiap karakter fisiologis, yang berpengaruh pada percepatan masa juvenil.

Kata kunci: fotosintesis, fruktosa, glukosa, rasio klorofil

* Penulis untuk korespondensi. e-mail: dedenmatra@apps.ipb.ac.id 


\section{PENDAHULUAN}

Mangga Kasturi (Mangifera casturi Kosterm) merupakan salah satu kekayaan buah lokal Indonesia yang merupakan tumbuhan endemik Kalimantan Selatan. Mangga Kasturi memiliki beberapa variasi di alam seperti Kasturi, Pelipisan, Cuban dan Pinari (Matra et al., 2021), dapat tumbuh mencapai $20 \mathrm{~m}$ dengan diameter batang 40$115 \mathrm{~cm}$ (Darmawan, 2015). Mangga Kasturi saat ini sudah masuk pada kategori langka di alam atau extinct in the wild menurut IUCN Red List tahun 2016 (Rhodes dan Maxted, 2016). Permasalahan ini salah satunya diakibatkan oleh mangga Kasturi yang belum memiliki teknik budidaya yang standar, umumnya hanya tumbuh alami di alam dengan biji dan memiliki umur yang cukup lama (Sari, 2014).

Cahaya diperlukan sebagai energi untuk mensintesis karbon dioksida dan air untuk menjadi karbohidrat dan oksigen pada proses fotosintesis. Cahaya memiliki bentuk sebagai partikel dan gelombang dengan warna cahaya yang paling banyak diserap adalah cahaya biru $(430 \mathrm{~nm})$ dan cahaya merah (660 nm) (Liu, 2012). Penggunaan cahaya buatan telah banyak diaplikasikan pada beberapa jenis tanaman, seperti menginduksi pembungaan pada tanaman strawberry (Fragaria x ananassa 'Pechka') dengan menggunakan cahaya biru (Magar et al., 2018), membuahkan blueberry pada saat tidak ada musim dan meningkatkan kandungan antosianin buah (Aung et al., 2014) dan mempercepat perkecambahan dari biji Dyctoneura acuminate Blume menggunakan cahaya merah dan merah jauh (Wardani dan Latifah, 2016).

Penelitian pemberian cahaya LED pada tanaman tahunan belum banyak dilaksanakan. Penelitian ini diharapkan dapat memberikan gambaran mengenai penambahan cahaya LED pada pembibitan mangga Kasturi dengan mengamati perubahan respon secara fisiologis bibit mangga Kasturi dengan penambahan cahaya pada spektrum cahaya yang berbeda.

\section{BAHAN DAN METODE}

Penelitian dilaksanakan pada bulan Januari hingga Juni 2021 di rumah paranet $(>90 \%)$, Kebun Percobaan Leuwikopo, Departemen Agronomi dan Hortikultura, Institut Pertanian Bogor. Pengamatan laboratorium dilaksanakan di Laboratorium Mikroteknik, Laboratorium Terpadu Seed Center, Departemen Agronomi dan Hortikultura, Institut Pertanian Bogor.

Penelitian dirancang menggunakan rancangan petak tersarang dengan dua faktor yaitu 3 jenis cahaya LED sebagai petak utama (LED merah, LED putih dan LED biru) dan 3 aksesi mangga Kasturi sebagai faktor yang disarangkan (aksesi Cuban, aksesi Pelipisan, dan aksesi Kasturi).

Bahan penelitian menggunakan bibit mangga Kasturi dari 3 aksesi yaitu Cuban, Pelipisan dan Kasturi, yang berasal dari Kalimantan Selatan disemai pada tanggal 16 Januari 2020. Bibit dengan umur 1 tahun disimpan di pembibitan dengan menggunakan paranet $90 \%$. Pemasangan lampu dilaksanakan dengan jarak antara lampu dengan kanopi tanaman adalah $45 \mathrm{~cm}$. Lampu LED yang digunakan merupakan LED dengan spektrum tunggal terdiri dari LED merah, putih, dan biru, LED dengan tipe strip SMD 5050 modul 6 mata, dengan tiap tanaman digunakan 5 strip di atas kanopi, dan disinari selama 20 jam, dari pukul 04.3000.30 WIB, sementara kondisi gelap pada pukul 00.3004.30 WIB, pada kondisi gelap ini dipilih pada waktu dengan suhu harian terendah. Intensitas cahaya diukur dengan menggunakan Licor-250A sebagai data logger, yang menampilkan nilai photosynthetically active radiation (PAR) dan nilai Photometric. Li-190R untuk mengukur nilai PAR. Nilai PPFD (Photosynthetic photon flux density) tiap jenis LED adalah LED merah: $1.72 \mu \mathrm{mol}^{-1} \mathrm{~s}^{-1}$; LED putih: $4.48 \mu \mathrm{mol} \cdot \mathrm{m}^{-1} \mathrm{~s}^{-1}$; LED biru: $4.77 \mu \mathrm{mol} \cdot \mathrm{m}^{-1} \mathrm{~s}^{-1}$.

\section{Pengukuran Klorofil a dan b}

Daun yang dianalisis berukuran $0.56 \mathrm{~cm}^{2}$, kemudian daun diekstraksi dengan menggunakan methanol, selanjutnya disimpan pada mikrotube dan ditambahkan metanol kembali hingga $1 \mathrm{~mL}$. Ekstraksi daun kemudian disentrifugasi selama 2 menit pada 11,200 rpm, setelah 2 menit dihasilkan larutan supernatan dan endapan pellet. Larutan supernatan kemudian dipindahkan $0.2 \mathrm{~mL}$ pada microplate, kemudian dibaca dengan menggunakan Multiskan ${ }^{\mathrm{TM}}$ FC Microplate photometer dengan pembacaan panjang gelombang A652, A665 (Warren, 2008).

\section{Pengukuran Laju Fotosintesis}

Pengamatan fotosintesis dilakukan dengan menggunakan Li-6800. Daun yang diamati adalah daun yang terpapar sinar secara merata.

\section{Pengujian Glukosa dan Fruktosa}

Daun dengan ukuran $0.79 \mathrm{~cm}^{2}$ dimasukkan dalam larutan ethanol $80 \%, 1 \mathrm{~mL}$ dengan suhu $80^{\circ} \mathrm{C}$ selama 20 30 menit dan diulangi proses penambahan ethanol hingga tiga kali. Setelah tiga kali ekstraksi didapatkan dua fraksi yang larut dan tidak mudah larut. Fraksi larut yang telah di keringkan kemudian dicampur dengan larutan 99\% klorofom: aquades (v/v), dengan campuran 1:2. Fraksi larut yang telah tercampur disentrifugasi dengan kecepatan 2,200 RPM selama 3 menit, untuk memisahkan gula yang larut pada air serta jaringan lemak dan klorofil yang larut dalam klorofom. Larutan kemudian dipipet sebanyak $3 \mu \mathrm{l}$ pada microplate dan selanjutnya dilanjutkan pengukuran glukosa dan fruktosa berdasarkan pengujian kit K-FRGLQR dilakukan menggunakan Multiskan ${ }^{\mathrm{TM}}$ FC Microplate photometer dengan panjang gelombang $340 \mathrm{~nm}$ (Lanoue et al., 2019).

\section{Pengukuran Ketebalan Daun dan Stomata}

Pengukuran dilakukan pada kerapatan stomata dan ketebalan daun menggunakan mikroskop pada perbesaran 40x (Hyeneke et al., 2013). 


\section{HASIL DAN PEMBAHASAN}

\section{Kandungan Klorofil a dan $b$}

Klorofil memiliki peran sebagai aparatur penangkap cahaya dengan spektrum warna merah dan biru. Berdasarkan percobaan yang telah dilaksanakan pemberian cahaya LED memberikan pengaruh nyata pada kandungan klorofil a, tetapi tidak berpengaruh pada kandungan klorofil $b$ dan rasio klorofil a/b. Cahaya LED merah memberikan pengaruh terbaik pada kandungan klorofil a (Tabel 1). Cahaya merah umumnya berperan pada perubahan morfologi tanaman, sedangkan cahaya biru berperan pada aparatur fotosintesis seperti pembentukan kloroplas dan formasi klorofil (Heo et al., 2012). Cahaya dengan intensitas tinggi cenderung mempercepat terjadinya degradasi pigmen sehingga dapat menurunkan kandungan klorofil lebih cepat, seperti pada tanaman sage pada intensitas tinggi lebih cepat mendegradasi klorofil (Rezai et al., 2017). Cahaya biru juga diketahui lebih memperbaiki kualitas biosintesis dari klorofil dibandingkan kuantitas dari klorofil pada tanaman selada, sehingga mengefesiensikan fotosisntesis pada tanaman (Son dan Oh, 2013). Pada penelitian ini cahaya biru menghasilkan nilai rasio klorofil a/b lebih rendah dari cahaya merah, rasio klorofil yang lebih rendah justru lebih mengefisienkan pada penangkapan cahaya oleh tanaman. Penurunan rasio ini akan meningkatkan asimilasi dari karbon dioksida, dan kandungan gula dan pati pada tanaman (Biswal et al., 2012)

\section{Parameter Fotosintesis}

Respon fisiologis dari penambahan cahaya LED pada penelitian ini didapatkan hasil bahwa tanaman memiliki perbedaan respon pada hasil fotosintesis. Beberapa faktor yang diamati pada pengamatan fotosintesis adalah: nilai cahaya yang diterima dan diabsorbsi, konduktansi stomata, laju fotosintesis, dan laju transpirasi tanaman (Gambar 1).
Pengukuran nilai laju fotosintesis didapatkan hasil laju fotosintesis tertinggi ada pada LED biru (Gambar 1C). Laju fotosintesis pada LED biru diketahuimemilikinilaiyang lebih tinggi dibanding cahaya lain, hal ini disebabkan LED biru akan menginduksi fotoreseptor cahaya biru yaitu fototropin (Briggs et al., 2007). Fototropin ini akan menginduksi perpindahan kloroplas dimana akumulasi dari kloroplas yang berkumpul menjadi satu menyebabkan tanaman dapat melakukan fotosintesis dalam kondisi defisiensi cahaya (Eckstein et al., 2012). Aplikasi penggunaan LED biru juga menghasilkan pengaruh pada efisiensi laju fotosintesis pada tanaman timun yang laju fotosintesisnya lebih efisien pada penggunaan cahaya biru dibandingkan merah (Hogewoning et al., 2010) dan selada karena peran cahaya biru yang menjaga intergritas kloroplas (Muneer et al., 2014). Pada cahaya merah walaupun nilai cahaya yang diterima paling rendah tetapi nilai fotosintesis (Gambar 1B) lebih efisien dibanding cahaya putih hal ini bisa disebabkan oleh kandungan klorofil cahaya merah pada daun yang tinggi (Tabel 1). Kandungan pigmen yang tinggi pada daun akan menyebabkan tanaman mengabsorbsi cahaya lebih efisien, yang akan menyebabkan tanaman menerima keseimbangan karbon pada kondisi cahaya yang defisit.

\section{Kandungan Glukosa dan Fruktosa}

Pengukuran kandungan glukosa dan frukosa pada penelitian ini didapatkan hasil spektrum LED berpengaruh pada perubahan kandungan glukosa dan fruktosa, sedangkan aksesi tidak memiliki pengaruh. Penambahan cahaya LED biru diketahui memberikan hasil terbaik pada kandungan glukosa pada daun tanaman, sementara pada kandungan fruktosa terbaik ada pada penambahan LED putih (Tabel 2). Lampu LED merah diketahui memberikan pengaruh nilai glukosa dan fruktosa yang lebih rendah dibandingkan dengan perlakuan cahaya putih dan biru, pada tanaman tomat juga diketahui aplikasi LED merah tunggal menurunkan nilai kandungan glukosa tanaman (Li et al., 2021). Hal ini bisa

Tabel 1. Kandungan klorofil a dan b pada tiga aksesi mangga Kasturi setelah penyinaran pada beberapa jenis lampu LED

\begin{tabular}{|c|c|c|c|}
\hline Perlakuan & Klorofil a $\left(\mu \mathrm{g} \mathrm{mL}^{-1}\right)$ & Klorofil b $\left(\mu \mathrm{g} \mathrm{mL}^{-1}\right)$ & Rasio a/b \\
\hline \multicolumn{4}{|l|}{ LED } \\
\hline Merah & $301.10 \mathrm{a} \pm 9.9$ & $137.53 \mathrm{a} \pm 4.89$ & $2.20 \mathrm{a} \pm 0.03$ \\
\hline Putih & $222.02 b \pm 13.34$ & $102.77 \mathrm{a} \pm 8.73$ & $2.25 \mathrm{a} \pm 0.12$ \\
\hline Biru & $212.62 b \pm 14.63$ & $100.42 \mathrm{a} \pm 8.50$ & $2.18 \mathrm{a} \pm 0.07$ \\
\hline \multicolumn{4}{|l|}{ Aksesi } \\
\hline Cuban & $215.54 \mathrm{a} \pm 17.20$ & $95.16 \mathrm{a} \pm 8.36$ & $2.32 \mathrm{a} \pm 0.11$ \\
\hline Pelipisan & $250.54 \mathrm{a} \pm 16.15$ & $122.19 \mathrm{a} \pm 9.18$ & $2.09 \mathrm{a} \pm 0.05$ \\
\hline Kasturi & $262.06 \mathrm{a} \pm 14.44$ & $120.32 \mathrm{a} \pm 7.40$ & $2.21 \mathrm{a} \pm 0.06$ \\
\hline Interaksi & tn & tn & tn \\
\hline
\end{tabular}

Keterangan: Nilai tengah yang diikuti oleh huruf yang sama pada kolom yang sama menunjukkan tidak berbeda nyata pada hasil uji DMRT dengan taraf 5\%. tn = tidak nyata 
disebabkan oleh proses oksidasi dari glukosa yang lebih cepat dibanding cahaya lain pada cahaya merah. Daun selada yang disinari cahaya merah akan meningkatkan aktifitas enzim degradasi sukrosa dan menurunkan aktifitas enzim sukrosa sintase yang mempengaruhi kandungan glukosa dan fruktosa (Chen et al., 2019). Kandungan gula yang tinggi juga dapat membantu pergerakan organel sel pada daun seperti pada kloroplas (Banas et al., 2012; Ekstein et al., 2012), sehingga pada Tabel 2 pada cahaya biru nilai kandungan gula yang tinggi juga mempengaruhi fotoreseptor fototropin cahaya biru untuk melakukan perpindahan kloroplas sehingga terjadi efisiensi laju fotosintesis (Gambar 1).

\section{Ketebalan Daun dan Kerapatan Stomata}

Stomata berperan penting pada kegiatan fotosintesis dan transpirasi tanaman, penambahan cahaya LED spektrum tunggal merah, biru dan putih pada bibit mangga Kasturi tidak berbeda nyata pada kerapatan stomata (Tabel 3). Penelitian ini diketahui penambahan cahaya LED tidak memberikan pengaruh nyata, bisa disebabkan oleh intensitas cahaya yang ditambahkan dalam intensitas kecil, sedangkan ruangan pembibitan dalam kondisi gelap, sehingga tidak terjadi pengaruh. Kerapatan stomata akan meningkat pada kondisi intensitas cahaya tinggi dibandingkan kondisi ternaungi (Kardiman dan Raebild, 2017). Penambahan cahaya LED juga tidak memberikan pengaruh nyata pada ketebalan daun, tetapi berdasarkan hasil daun yang disinari cahaya putih lebih tebal dari cahaya lain (Tabel 3). Daun yang terekspos cahaya dengan intensitas tinggi akan menyebabkan jaringan mesofil yang lebih padat dikarenakan adanya penambahan tinggi palisade dan berkurangnya ruang intraseluler. Anatomi daun berperan sebagai kontrol penerimaan cahaya, adanya perubahan sel palisade, dan pemanjangan sel pada bagian adaxial daun akan menyebakan efisiensi dalam penyerapan cahaya merah dan biru (Silvestri et al., 2019). Penurunan nilai ppfd cahaya biru dan peningkatan rasio cahaya merah menurunkan ketebalan daun pada Ficus benjamina (Zheng dan Van Labake, 2017). Pada penelitian ini daun yang disinari LED merah menghasilkan ketebalan daun yang lebih tipis dibandingkan LED lain, hal ini bisa disebabkan juga karena nilai ppfd cahaya yang terendah. Intensitas cahaya rendah juga diketahui mempengaruhi ketebalan daun menjadi lebih tipis pada tanaman kedelai yang ditanam pada kondisi defisit cahaya (Muhuria et al., 2006).
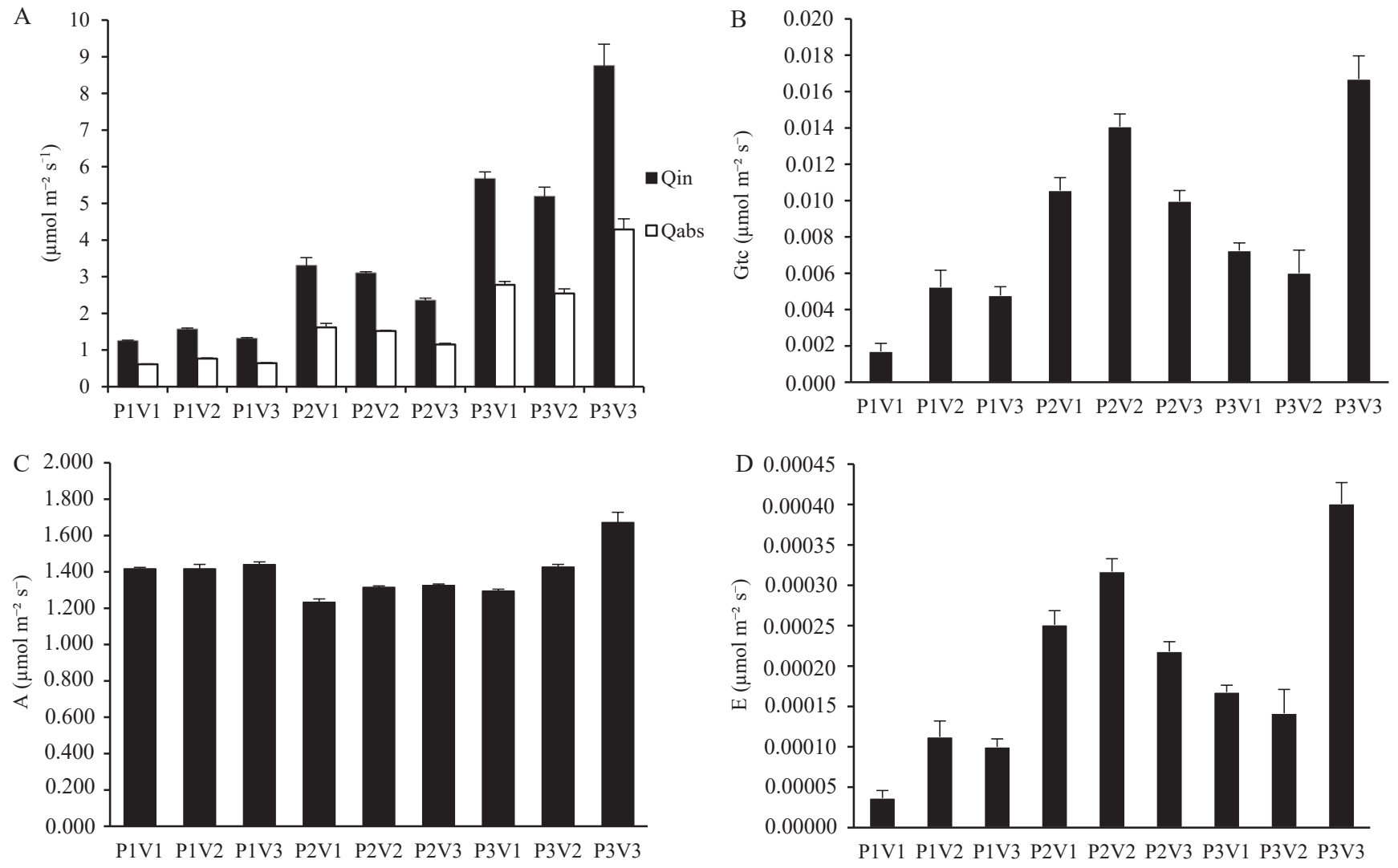

Gambar 1. Nilai Pengukuran menggunakan fotosintesis pada perlakuan LED merah, putih dan biru di atas kanopi (A) Nilai cahaya yang diterima dan diabsorbsi mangga Kasturi, (B) konduktansi stomata, (C) laju fotosintesis, (D) laju transpirasi. P1V1 = Cuban LED merah; P1V2 = Pelipisan LED merah; P1V3 = Kasturi LED merah; P2V1 = Cuban LED putih; P2V2 = Pelipisan LED putih; P2V3 = Kasturi LED putih; P3V1 = Cuban LED biru; P3V2 = Pelipisan LED biru; P3V3 = Kasturi LED biru 
Tabel 2. Kandungan glukosa dan fruktosa pada tiga aksesi mangga Kasturi setelah penyinaran pada berbagai jenis lampu LED

\begin{tabular}{ccc}
\hline Perlakuan & $\begin{array}{c}\text { Glukosa } \\
\left(\mu \mathrm{g} \mathrm{mL}^{-1}\right)\end{array}$ & $\begin{array}{c}\text { Fruktosa } \\
\left(\mu \mathrm{g} \mathrm{mL} \mathrm{mL}^{-1}\right)\end{array}$ \\
\hline LED & & \\
Merah & $60.15 \mathrm{~b} \pm 0.78$ & $13.15 \mathrm{~b} \pm 0.63$ \\
Putih & $62.59 \mathrm{ab} \pm 0.61$ & $17.34 \mathrm{a} \pm 1.16$ \\
Biru & $63.65 \mathrm{a} \pm 0.75$ & $15.75 \mathrm{ab} \pm 0.87$ \\
Aksesi & \pm & \pm \\
Cuban & $62.32 \mathrm{a} \pm 0.97$ & $15.82 \mathrm{a} \pm 0.88$ \\
Pelipisan & $61.84 \mathrm{a} \pm 0.56$ & $15.56 \mathrm{a} \pm 1.17$ \\
Kasturi & $62.40 \mathrm{a} \pm 0.95$ & $14.97 \mathrm{a} \pm 0.89$ \\
Interaksi & tn & tn \\
\hline
\end{tabular}

Keterangan: Nilai tengah yang diikuti oleh huruf yang sama pada kolom yang sama menunjukkan tidak berbeda nyata pada hasil uji DMRT dengan taraf 5\%. tn $=$ tidak nyata

\section{KESIMPULAN}

Penambahan cahaya LED menghasilkan respon yang berbeda pada aspek fisiologis yang dihasilkan. Penambahan cahaya LED biru memberikan respon pada efisiensi fotosintesis, dan kandungan glukosa terbaik pada tanaman. Penambahan cahaya LED putih memberikan respon pada kandungan fruktosa terbaik dan menyebabkan daun lebih tebal dibandingkan dengan sumber cahaya lain. Penambahan cahaya LED merah memberikan respon pada kandungan klorofil a terbaik.

\section{UCAPAN TERIMA KASIH}

Penulis mengucapkan terima kasih kepada Lembaga Pengelola Dana Pendidikan (LPDP) Republik Indonesia sebagai penyandang dana pada penelitian dan pendidikan untuk Alifiya Herwitarahman. Penelitian ini dibantu sebagian dari hibah Penelitian Unggulan Perguruan Tinggi (PDUPT), KEMENRISTEK-BRIN Tahun 2019-2021 untuk Deden Derajat Matra.

\section{DAFTAR PUSTAKA}

Aung, T., Y. Muramatsu, N. Horiuchi, J. Che, Y. Mochizuki, I. Ogiwara. 2014. Plant growth and fruit quality of blueberry in a controlled room under artificial light. J. Soc. Hort. Sci. 83:273-281. Doi:10.2503/jjshs1. CH-110.

Banas, A.K., C. Aggarwal, J. Łabuz, O. Sztatelman, H. Gabrys. 2012. Blue light signaling in chloroplast movements. J. Exp. Bot. 63:1559-1574. Doi:10.1093/ $\mathrm{jxb} / \mathrm{err} 429$.
Tabel 3. Kerapatan stomata dan ketebalan daun pada tiga aksesi mangga Kasturi setelah penyinaran pada beberapa jenis lampu LED

\begin{tabular}{ccc}
\hline Perlakuan & $\begin{array}{c}\text { Kerapatan stomata } \\
\left(\mathrm{mm}^{-2}\right)\end{array}$ & $\begin{array}{c}\text { Ketebalan daun } \\
(\mathrm{mm})\end{array}$ \\
\hline LED & & \\
Merah & $444.22 \mathrm{a} \pm 18.74$ & $0.17 \mathrm{a} \pm 0.007$ \\
Putih & $466.33 \mathrm{a} \pm 12.61$ & $0.18 \mathrm{a} \pm 0.012$ \\
Biru & $441.16 \mathrm{a} \pm 16.74$ & $0.17 \mathrm{a} \pm 0.009$ \\
Aksesi & \pm & \pm \\
Cuban & $445.24 \mathrm{a} \pm 16.78$ & $0.17 \mathrm{a} \pm 0.008$ \\
Pelipisan & $449.66 \mathrm{a} \pm 17.15$ & $0.18 \mathrm{a} \pm 0.013$ \\
Kasturi & $456.80 \mathrm{a} \pm 15.33$ & $0.16 \mathrm{a} \pm 0.005$ \\
Interaksi & tn & tn \\
\hline
\end{tabular}

Keterangan: Nilai tengah yang diikuti oleh huruf yang sama pada kolom yang sama menunjukkan tidak berbeda nyata pada hasil uji DMRT dengan taraf $5 \%$. tn $=$ tidak nyata

Biswal, A.K., G.K. Pattanayak, S.S. Pandey, S. Leelavathi, V.S. Reddy, Govindjee, B.C. Tripathy. 2012. Light intensity dependent modulation of chlorophyll $b$ biosynthesis and photosynthesis by overexpression of chlorophyllide a oxygenase in tobacco. Plant Phys. 159:433-449. Doi:10.1104/pp.112.195859.

Briggs, W.R., T.S. Tseng, H.Y. Cho, T.E. Swartz, S. Sullivan, R.A. Bogomolni, E. Kaiseli, J.M. Christie. 2007. Phototropins and their LOV domains: versalite plant blue-lights receptors. JIPB. 49:4-10.

Chen, X.L., L.C. Wang, T. Li, Q.C. Yang, W.Z. Guo. 2019. Sugar accumulation and growth of lettuce exposed to different lighting modes of red and blue led light. Sci. Rep. 9:1-10. Doi:10.1038/s41598-019-43498-8.

Darmawan, A.R.B.. 2015. Review: Usaha peningkatan kualitas mangga Kasturi (Mangifera casturi) dengan modifikasi budi daya tanaman. Pros. Sem Nas Masy Biodiv. Indon. 1:894-899.

Eckstein, A., P. Zieba, H. Gabrys. 2012. Sugar and light effects on the condition of the photosynthetic apparatus of Arabidopsis thaliana cultured in vitro. J. Plant Growth Regul. 3:90-101. Doi:10.1007/s00344011-9222-Z

Heo, J.K., D.H. Kang, H.S. Bang, S.G. Gong, C. Chun, K.K. Kang. 2012. Early growth, protein content and phenylalanine ammonia-lyase activity of red curled lettuces grown under different lighting condition. Kor. J. Hort. Technol. 30:6-12. Doi:10.7235/ hort.2012.11118. 
Hogewoning, S.W., G. Trouwborst, H. Maljaars, H. Poorter, W.V. Leperen, J. Harbinson. 2010. Blue light-dose responses of leaf photosynthesis, morphology, and chemical composition of Cucumis sativus grown under different combinations of red and blue light. J Exp Bot. 61:3107-3117. Doi:10.1093/jxb/erq132.

Hyeneke, E., N.L. Ebengreuth, I. Krajcer, V. Wolkingwr, M. Muller, B. Zechan. 2013. Dynamic compartment specific changes in glutathione and ascorbate levels in Arabidopsis plants exposed to different light intensities. BMC Plant Biol. 13:1-19. Doi: 10.1186/1471-2229-13-104.

Kardiman, R., A. Raebild. 2017. Relationship between stomatal density, size and speed of opening in Sumatran rainforest species. Tree Physiology. 38: 696-705. Doi:10.1093/treephys/tpxt149.

Lanoue, J., J. Zheng, C. Little, Thibodeau, B. Grodzinki B, X. Hao. 2019. Alternating red and blue light-emiting diodes allows for injury free tomato production with continuous lighting. Front Plant Sci. 10:1-14.

Li, Y., Z. Liu, Q. Shi, F. Yang, M. Wei. 2021. Mixed red and ble light promtes tomato seedlings growth by influencing leaf anatomy, photosynthesis, $\mathrm{CO}_{2}$ assimilation and endogenous hormones. Sci Hort. 290:1-13. Doi:10.1016/j.scientia.2021. 110500.

Liu, W. 2012. Light environmental management for artificial protected horticulture. Agrotechnology 1:1-4. Doi: 0.4172/2168-9881.1000101.

Magar, Y.G., K. Ohyama, A. Noguchi, W. Amaki, S. Furufuji. 2018. Effects of light quality during supplemental lighting on the flowering in an everbearing strawberry. Acta Hortic. 1206:279-284. Doi:10.17660/ActaHortic.2018.1206.39.

Matra, D.D., M.A.N. Fathoni, M. Majidu, H. Wicaksono, A. Sriyono, G. Gunawan, H. Susanti, R. Sari, F. Fitmawati, I.S. Zulkarnaen, W.D. Widodo, R. Poerwanto. 2021. The genetic variation and relationship among the natural hybrids of Mangifera casturi Kosterm. Sci Rep. 11(19766). Doi:10.1038/ s41598-021-99381-y.
Muhuria, L., K.N. Tyas, N. Khumaida, Trikoesoemaningtyas, D. Sopandie. 2006. Adaptasi tanaman kedelai terhadap intensitas cahaya rendah: karakter daun untuk efisiensi penangkapan cahaya. Bul. Agron. 34:133-140.

Muneer, S., E.J. Kim, J.S. Park, J.H. Lee. 2014. Influence of green, red and blue light emitting diodes on multiprotein complex proteins and photosynthetic activity under different light intensities in lettuce leaves (Latuca sativa L.). Int.J.Mol.Sci. 15:46574670. Doi:10.3390/ijma15034657.

Rezai, S., N. Eternadi, A. Nikbath, M. Yousefi, M.M. Majidi. 2018. Effect of light intensity on leaf morphology photosynthetic capacity, and chlorophyll content in sage (Sage officinalis L). Hort. Sci. Tech. 36:46-57. Doi:10.12972/kjhst.20180006.

Rhodes, L., N. Maxted. 2016. Mangifera casturi. The IUCN Red List of Threatened Species 2016: e.T32059A61526819.

Sari, S.G. 2014. Kelimpahan dan penyebaran populasi Mangifera casturi sebagai usaha konservasi dan pemanfaatan tumbuhan langka khas Kalimanatan Selatan. EnviroScienteae. 10:41-48.

Silvestri, C., M.E. Caceres, M. Ceccarelli, A.L. Pica, E. Rugini, V. Critofori. 2019. Influence of continuous spectrum light on morphological traits and leaf anatomy of hazelnut plantlets. Front Plant Sci. 10:112. Doi:10.3389/fpls.2019.01318.

Wardani, F.F., D. Latifah. 2016. Perkecambahan biji Dicrtyoneura acuminate Blume. pada cahaya merah dan merah jauh. J. Hort. Indonesia 7:49-55.

Warren, C.R.. 2008. Rapid measurement of chlorophylls with a microplate reader. J. Plant Nut. 31:1321-1332. Doi:10.1080/01904160802135092.

Zheng, L., M.C. Van Labeke. 2017. Long-term effects of red and blue light emiting diodes on leaf anatomy and photosynthetic efficiency of three ornamental pot plant. Front Plant Sci. 8:1-12. Doi:10.3389/ fpls.2017.00917. 